\title{
Challenges and conservation implications of the parrot trade in Cameroon
}

\author{
Simon A. TAMUNGANG ${ }^{1 *}$, Moses A. OFEH ${ }^{2}$, Martin N. TCHAMBA ${ }^{3}$, \\ Robert A. $\mathrm{CHEKE}^{4}$ and Ghislain P. KOUGOUM ${ }^{5}$ \\ ${ }^{1}$ College of Technology, University of Bamenda, PO Box 2164 Bamenda, Cameroon. \\ ${ }^{2}$ Department of Economics, Higher Teachers Training College, University of Bamenda, \\ PO Box 39 Bambili, Cameroon. \\ ${ }^{3}$ Department of Forestry, Faculty of Agronomy and Agricultural Sciences (FASA), \\ University of Dschang, PO Box 222 Dschang, Cameroon. \\ ${ }^{4}$ Natural Resources Institute, the University of Greenwich at Medway, \\ Central Avenue, Chatham Maritime, Kent ME4 4TB, UK. \\ ${ }^{5}$ Department of Biological Sciences, Faculty of Sciences, University of Maroua. \\ PO Box 814 Maroua, Cameroon. \\ *Corresponding author; E-mail: atamungang@yahoo.com
}

\section{ACKNOWLEDGEMENTS}

Notably, special thanks go to the Ministry of Forestry and Wildlife, Cameroon, for providing a research permit and funds; the Loro Parque Fundacion, Spain provided funds.

\begin{abstract}
Humans in every culture exploit wildlife resources around them to satisfy their immediate needs using many different methods. Similarly, parrots are exploited in Cameroon in various ways, for both consumptive and non-consumptive uses, by many cultures there. Trading in parrots is the biggest form of wild bird exploitation, and it is carried out by both the public and the private sectors, to satisfy both local and international demands. This paper therefore examined the challenges and conservation implications of the parrot trade in Cameroon. Focus groups and ground research teams were used for data collection in the national territory. It was evident from the results that the main stakeholders in this trade were the government and the private sector, and the driving force behind the trade were unemployment and poverty. Primary sources of Grey Parrots were the three rainforest regions of Cameroon. The frequency of occurrence of the Grey Parrot in the trade exceeded the numbers of other parrot species traded. The future of the trade in Cameroon is not certain as some of its activities are not in harmony with modern approaches to sustainable wildlife conservation and management. These challenges form the basis of the debate on the consequences and conservation implications of the parrot trade in Cameroon.

(C) 2016 International Formulae Group. All rights reserved.
\end{abstract}

Keywords: Parrot trade, Grey parrot, Psittacus erithacus, conservation implications, wildlife, Cameroon 


\section{INTRODUCTION}

The trade in wildlife is an age-old practice known especially to the early Romans, Egyptians and Greeks. This practice gave birth to the International Trade in birds which has been going on for many centuries. Records go as far back as 1865 when exotic birds were traded in large numbers in the United States of America. Europe was then the largest annual supplier of thousands of birds, though most of these birds were harvested from Africa, Asia and South America (Traffic International, 1992; WWF, 1994). Since then, many people have continued to use wild caught birds and other wildlife species in captive environments as sources of livelihoods and companionship. Today, the practice of keeping wild-caught animals as pets varies from one country to the other as well as one culture to another. For example, some cultures prefer to use body parts of killed animals as opposed to living ones used elsewhere. Thousands of birds are removed from their natural habitats and sold legally or illegally to make quick money locally and internationally each year (Inskipp, 1990; Cooney et al., 2015). The trade has been estimated to amount two millions of US dollars a year (Toufexis, 1993; WWF, 1994). Although many exotic bird species could be purchased legally, trade in birds and other animals that are in imminent danger of extinction (Endangered species) is banned under the United Nations Convention on International Trade in Endangered Species (CITES), whereby 147 countries accepted the amendment to Article XI of the Convention adopted at Bonn (Germany), on 22 June 1979 and applied on 13 April 1987 (CITES, 2016). Recent information shows that a majority of the birds in the trade are passerine or songbirds (Order Passeriformes). Psittacines (Order Psittaciformes, consisting of parrots) form the second largest group of birds in the International bird trade (Wyler, 2008; Birdlife International, 2016).
According to an earlier CITES report on trade in Psittacines, from 1982-1988, parrots in the trade ranged from a low value of 476,917 birds per year to a high value of 624,198 and an average of 539,701 birds per year (Broad, 1990). Recent data show that other avian orders are present in small numbers in this trade (Wyler, 2008). Most wildlife conservationists and animal welfare groups see the International pet trade as an ecological disaster. For example, thousands of Grey Parrots Psittacus erithacus die during the process of trapping, transportation and domestication. Crude methods of trapping the birds add to their death toll while the loss of habitat is even more devastating than trapping since all animals in the area may be threatened, or they may die or are forced to migrate as the ecological web is disrupted. Diseases associated with caged birds, both wild caught and captive bred, pose another threat to native species as well as to domestic birds (Stuart et al., 2006; Brooks-Moizer, 2009). Attempts to curb the trade have yielded minor success in the past few years. Some non-governmental organisations (NGOs) and some national governments have expressed concern that trapping wild birds to support foreign pet markets may be depleting wild avian populations (Herrera, Hennessey, 2007). Animal welfare organisations are of the opinion that the trade treats birds inhumanely. These institutions succeeded in convincing many airlines to stop carrying wild caught birds. By October 1992, over 40 carriers had accepted not to transport such birds (Traffic International, 1992; Conrad, 2012). By July 1993, over 100 airlines had complied with the refusal request to transport wild-caught live birds (Toufexis, 1993). Recently, several initiatives have been taken to address the International bird trade in the context of CITES (WWF, 2008).

In 1990, the CITES Animals Committee formed a Working Group on Bird Trade to examine the International trade in 
wild-caught birds more carefully. The trade was also placed on agendas of national governments in major consumer markets of the United States and Europe. In the United States, the Co-operative Working Group on Bird Trade, composed of representatives from conservation, animal welfare, avi-cultural and pet industry organisations, developed a series of recommendations to address problems associated with the trade (Wyler, 2008; AFA, 2016). In Europe, the European Parliament adopted a resolution calling for a ban on the European Union (EU) imports of wild-caught birds for the pet trade in response to a campaign launched by animal welfare and bird protection organisations (Bush, 2014). The International Bird trade will remain the subject of debate for some time to come, regardless of the forum for discussion. In this scenario, implementing the CITES treaty on wildlife trade remains a huge challenge, likewise enforcing the stringent laws against wildlife smuggling that exist in many nations.

Africa is a major source of wild-caught parrots in the International pet trade (Mulliden, 1995). Favorite African birds in the trade include Grey Parrots ( $P$. erithacus and P. timneh), Lovebirds (Agapornis spp.) and members of the genus Poicephalus (e.g. Senegal Parrot $P$. senegalus; Myer's parrot $P$. Myeri) (Bush et al., 2014). The Grey Parrot P. erithacus is the species discussed in this paper, and it is endemic to lowland rainforests of West and Central Africa. Its close relative the Timneh Grey Parrot $P$. timneh occurs further west from Ivory Coast to Sierra Leone. $P$. erithacus is the third most traded bird in the world, a popularity attributed to its intelligence and mimetic abilities (Pepperberg, 1998). So far, not much research has been carried out on the ecology and conservation of the wild Grey Parrot in Cameroon. The first long-term population estimates to justify the export quotas of the Grey Parrot were conducted by Fotso (1998). Another population estimate was carried out by
Tamungang and Cheke (2012). However, without field monitoring and implementation of prescribed projects, there is no evidence support the view that the CITES export quotas are sustainable. This study conducted socioeconomic and socio-ecological surveys to evaluate parrot species exploitation activities and trade levels with the goal of contributing to a course of action for sustainable parrot population management in Cameroon.

\section{MATERIALS AND METHODS}

\section{Study area}

The study covered the national territory of the Republic of Cameroon, located at latitude $3^{\circ} 51^{\prime} 59.99^{\prime \prime} \mathrm{N}$ and Longitude: $11^{\circ}$ $30^{\prime} 59.99^{\prime \prime}$ E. The country covers a surface area of $475,385 \mathrm{~km}^{2}$ and has a coastline of 402 $\mathrm{km}$. It is roughly triangular in shape with a North-South length of $1400 \mathrm{~km}$, and a maximum width from East to West of $800 \mathrm{~km}$. The country is bounded to the South by the Republics of and Equatorial Guinea, Gabon and Congo and the Atlantic Ocean; to the West by the Republic of Nigeria; to the North by Lake Chad and to the East by the Republic of Chad and the Central African Republic (Figure 1).

Cameroon's ethnic composition is diverse with approximately 200 ethnic groups that make up the 23.7 million Cameroonians (WRI, 2012). Its varied climate makes Cameroon a global hotspot for flora (Figure 1) and fauna (Bobo and Waltert, 2011; Sandjong et al., 2013; Tsakem et al., 2015; Ngoule et al., 2015). Cameroon has relied on agriculture and timber for its export earnings for decades; this includes extensive cocoa and rubber plantations in the southern part of the country. Cameroon is a leading exporter of forest products in Africa. The forest sector is Cameroon's largest non-public sector employer and its second largest source of export revenue after petroleum, accounting for $28 \%$ of non-petroleum exports (MINFOF, 2007). 
The country can be divided into four topographical zones. There is a small coastal plain located in the south, which harbours the equatorial rainforest and swamplands along its edges bordering the Atlantic Ocean (Figure 1). The Savannah covers the plateau in its northern centre, called the Adamawa Plateau. Next to the plateau are a mountainous area in the west, harbouring portions of the low and highland forests, and the active volcano of Mount Cameroon. Lastly, there is a rolling sub-arid Savannah interspersed with Sahel vegetation (Ngoule et al., 2015) located in the extreme north of the country (Figure 1). The northern zone is drained by the Logone and Chari Rivers, which finally empty into the Lake Chad Basin. The other main rivers are the Wouri, Sanaga, Dibamba, and Nyong, all of which drain into the Gulf of Guinea. Land use is varied from one part of the country to another depending on the vegetation type available, but major categories are: forested zone, $77 \%$; pasture zone, $4 \%$; agriculturalcultivated zone, $15 \%$ and other zones, $4 \%$ (FAO, 2010). These figures are gradually changing with the increase in population growth and high socioeconomic pressures on land-use patterns. Cameroon is imbued with a tropical climate which varies from equatorial in the south to Sahel in the north. The Sahel climate has a wet season between April and September while the rest of the year is dry. An average annual precipitation for this region is between 1,000 and 1,750 mm. The Southern Equatorial part has two rainy seasons and two dry seasons, with the early rainy season between March and June and the late rainy season between August and November, while the early dry season is between June and August and the late dry season is between November and March. However, it should be noted that these seasonal patterns are being affected by climate change factors. Average temperature ranges in Yaoundé are from 18 to 29 degrees Celsius with a mean annual precipitation of 4,030 $\mathrm{mm}$ (MENEP, 2009).

\section{Research team formation}

Data collection, which took place from 2006-2008, was preceded by a workshop to identify methods to be used in the field. Thirty-three (33) persons from various multidisciplinary professions were invited to a workshop in February 2006 at the French Cultural Centre in Dschang. The workshop had one primary objective: to develop standard methods that can be used for monitoring and evaluating the Parrot trade in Cameroon regarding sustainability. At the end of the workshop, participants came up with methods that were to be used for data collection by this project. A PARROTPRO multidisciplinary research team was then formed following the workshop with most members being selected from the workshop participants. Some skilled members who could not attend the workshop for one reason or another were also selected. Selection criteria included academic qualification, area of research and experience acquired. The research team was made up of conservation biologists, economists, statisticians and environmentalists. The Cameroonian Ministry of Forests and Fauna (MINFOF) as a presentative of the Government of Cameroon in the management of wildlife trade issued a special Research Permit for field data collection to PARROTPRO.

The Stratified Sampling Method was used for field data collection (Hill et al., 2005). Data were collected using open and close-ended questionnaires and direct observations. Themes addressed by questionnaires include; where and how parrots were trapped, trapping and transportation activities, parrot welfare in captivity, trade chains and challenges. Targeted groups of persons for data collection were:

- Wildlife trappers (licensed and nonlicensed),

- Wildlife traders (exporters and local parrot traders), 
- Villagers (notables, farmers and hunters),

- Conservation agents (Government administrators and NGO agents),

- Law enforcement agents

Efforts were made to gather literature on the parrot trade in and out of Cameroon. Notably, prices of African parrots especially the Grey Parrot were obtained from Europe and the United States of America using internet sources and contacted persons.

Data were collected in the ten regions of Cameroon (Figure 2) as the largest units of stratification; subunits for stratification were the Administrative Divisions. Districts and villages were then randomized. The Project team worked in each region in collaboration with the Regional Delegate of MINFOF, who in turn supervised Divisional Delegates of MINFOF. The Divisional delegates worked directly with the local population and protected area personnel. There were no particular seasons for data collection, but a timetable was followed each month and systematically covered the whole country. However, it was important for investigators to monitor and observe seasonal trapping of parrots. On arrival in a village with few literate persons, a native of the village was hired to translate the questions and the answers.

The method of using government law enforcement officers of the Ministry of Forestry and Wildlife to collect data was not very effective. Some villagers and illegal trappers were reluctant to give information to them as they were afraid to be identified with illegal parrot trading. To reinforce efficient data collection, volunteers were employed to assist in data collection. The volunteers were mostly graduate and undergraduate students of Universities in Cameroon.

\section{Appraisal of the Forestry and Wildlife Law}

An Appraisal of Law No. 94-01 of January 1994 to lay down Forestry, Wildlife and Fisheries Regulations in Cameroon was carried out as a case study for the conservation of parrot species in Cameroon. The research team reviewed the law and its accompanying texts of application. The overall objective of this review was to identify weaknesses of the law and make recommendations that will take care of the specific interest of the sustainable conservation of parrot species in Cameroon. A multidisciplinary committee of seven persons brought out strengths and weaknesses that can be used to enhance parrot species conservation in Cameroon.

Final data sets were synthesized and analysed using relevant statistical packages. Non-parametric analyses, such as Chi-Squared test and Spearman's correlation were used to establish pair-wise comparisons of relevant the datasets collected from the national territory. Other data were pooled to estimate the mean \pm SE using Analysis of Variance (ANOVA). In addition, the one-way Analysis of Variance (ANOVA) was used to compare prices of parrots in the regions of the country and in seasons over the period of study at the 0.05 level of significance. Where there was a significant difference statistically, Duncan's multiple range test was used to identify the cause of the difference. To find out if there was any interaction between regions and seasons, a two-way ANOVA test was carried out.

\section{RESULTS \\ Trapping of parrots}

The parrot trade begins with trapping of wild parrots in the rainforest regions of Cameroon. Parrots are trapped all year round depending on the demand, parrot species behaviour and the trapping method. They are either trapped in the day or night, depending on the site and method used. For example, villagers usually capture most parrots during fruiting periods of trees like the plum (Dacryodes edulis), which ripens during the rainy season, when they come in great flocks 
to eat plums. Trapping methods of parrots vary from one part of the country to another. However, favourite techniques are the gum and stick, and nets.

\section{Trapping methods}

A summary of trapping methods is presented below:

1. Glue and stick: The sap (latex) of some wild plants and broomsticks from palm trees were used for trapping the birds in two significant ways.

a. At roosts, long bamboo and glue on broomsticks are used to bind their wings thus disabling the bird from flying.

b. At feeding sites, the broomsticks are rubbed in glue and placed on tree branches, and they stick on the feathers of the birds. As such, they are not able to flap their wings so that they fall from the tree. In this case, tree branches may be used to hold the broomsticks instead of bamboos.

2. Nets: Fishing nets were usually used, and the bird gets itself entangled in them. They were used at:

a. Feeding sites on groundnut farms and swampy areas where the birds often feed on weed and soils (geophagy).

b. They were also used at roosts where they were attached to two or more poles. The birds are then frightened from the opposite direction towards the net in which they get entangled.

3. Thread and sticks:

a. A tiny nylon thread is made in the form of a trap and tied to a stick and driven into the ground at feeding sites. This type of trap catches the bird on the leg.

b. The thread was also used at roosts whereby it was skillfully placed on the spot where the bird perches to roost and it caught the bird on the leg.

4. Climbing a tree to remove the young parrot from the nest. Existing known nests are monitored by observing activities of parent birds at the nesting site especially during the breeding season.

5. Felling a tree to remove juvenile birds from the nest. This method is rarely used because it is cumbersome to fell a tree. The method was frequently used when the tree can be felled and used for timber. In this case, the villagers wait until they are sure that there are chicks in the nest before felling the tree. Many drivers of timber exploitation companies had reported catching young parrots when the trees were felled in the forest.

6. Use of pepper and some other natural products to suffocate a bird at roost. This method is not widely used and the use of chemicals to catch animals is banned by the 1994 Forestry and Wildlife law in Cameroon.

7. Use of anaesthesia and tranquillizers on birds at roost. The use of chemical products to catch animals is banned by the 1994 Forestry and Wildlife law in Cameroon.

8. Use of catapult to shoot the bird in flight or on a perch. The use of a catapult is a traditional standard method used for catching a bird for local use in villages. The bird is usually shot dead, and it is eaten as food. Useful parts of the bird like the red feathers, head or legs may be removed and preserved for sale or used for traditional medicine. This method is not used for getting birds for commercial purposes because the output is very low. Most people use this method for pleasure.

9. Use of a gun with cartridges: This is another traditional method of getting the bird in the village. Usually, it is the local or traditional or artisanal gun (also called dane gun) that is used. A modern gun is hardly used, and the bird is obtained dead, caused by the cartridges or pellet used for loading the gun. This method is mostly used by people who want to get the feathers and other body parts of the bird for traditional use. Some villagers told the investigators that it is not economical to use a gun to shoot a parrot because the price of loading the gun is higher than the benefit to be obtained from the dead 
bird, only if the bird is to be used as food.

10. Use of bow and arrow: This method is very rarely used in Cameroon though it was reported to be used in some villages especially during the fruiting season of plums, when the birds come around farms and human settlements.

11. Use of hand held explosives: This is the most dangerous method of killing the Grey Parrot. It was reported in the South and Centre Regions. The poacher uses handheld explosives to kill parrots that gather in large flocks at feeding sites. He then collects them, chops off the heads, legs and feathers and preserves them dried. The preserved body parts are sold locally and smuggled out of Cameroon for sale. Such body parts are said to be used by traditional doctors. This method of catching parrots is the most dangerous ever employed in Cameroon on parrots, and the culprit is seriously punished by the 1994 Forestry and Wildlife Law of Cameroon.

\section{Transportation}

The method used for the transportation of wild parrots is a major factor that determines their survival rate for subsequent utilization. The shorter the distance between the place of trapping to the aviary, the better the success rate. Unfortunately, parrots are nowadays mostly found in remote parts of Cameroon with difficult means of accessibility by road. Some trappers do not care much to reduce mortality (by taking good care of the birds before and during trapping) especially if they trap their birds illegally. As such, they can stuff as many parrots in a cage or box as possible, and place them in obscured and poorly ventilated places to pass through police checkpoints unnoticed. Some illegal trappers stuck live parrots in baskets covered with thick clothes or stuck them in spare tyres and other unfavourable means for transport to cities and towns. Many hunters hold parrots in a cruel and uncaring manner and do not bother about the agonising cry of the bird. In most cases, the hunters lack the basic training and experience in holding a wild bird well. Some of them say that "it is just a bird" and so, as such, can be held in any manner without caution or pity.

Some birds die in transit also from physiological stress, lack of food and drinking water. The trapper may introduce food items in the cage that the wild caught bird is not familiar with and it refuses to eat. All sexes and ages are captured and no breeding season is observed. This study estimated that 3-5 parrots die out of every 35 from the forest before arriving at the trappers' home. Therefore, out of 3500 trapped birds, 300 $500(8.57-14.29 \%)$ of them were likely to die. The more checkpoints on the road and the longer the road, the more the likelihood that more parrots will die. There is also a possibility of disease transfer when sick birds are mixed with healthy ones. However, experienced trappers have a higher probability of their parrots having low mortality rates during transportation. People who transport parrots with their valid documents did not encounter many losses of parrots, and their parrots experience less stress and as such are healthy.

\section{Stakeholders of the parrot trade and their roles Trappers}

Trappers are usually young men between the ages of 20-45, who have acquired experience on trapping techniques. The knowledge is usually acquired through going to the field with older trappers. Most of the trappers live in villages, trap parrots and travel to urban areas to sell or supply to their trading bosses. Two categories of trappers identified were the part-time and full-time trappers. The part-time trappers trap the birds seasonally when they are abundant such as during plum (Dacryodes edulis) harvesting seasons. They also carry out this activity when there is a particular demand from a boss such as an exporter. This type of trapper has an 
alternative source of income (such as a cocoa farm) on which he and his family depend on complement livelihoods. Full-time or professional trappers trap the birds all year round and have regular outlets for selling the birds.

Most of them live in semi-urban areas but go to villages to catch the birds. They have bosses such as exporters or local sellers who buy the birds to resell. Questionnaires analysis showed that $54 \%$ of the trappers were married and $40 \%$ single, $94 \%$ of them were males and only $4 \%$ were females (Figure 3 ). This observation was the first to document female trappers in the parrot trade sector in Cameroon. The survey further revealed that $47 \%$ of the trappers were self-employed with parrot trapping and small businesses (Figure 3). Judging from the fact that $54 \%$ of them were married with children and extended families to take care of, it is evident that they must have an alternative means of generating income. It was the same situation with the second group (scoring 40\%) who carried out hunting and subsistence agriculture. Civil servants $(4 \%)$ were also involved in the trapping as a part-time job to augment their low salaries. Students (4\%) also found time during weekends and holidays to trap parrots as additional income to get school needs.

\section{Village communities}

Communities are supposed to receive some royalties from the government and trappers for conserving parrots in their forests. The royalty will contribute significantly to letting them know that they are stakeholders in parrotconservation, and this will also encourage them to take care of the wild parrots. $92 \%$ of the respondents indicated that parrot exploiters do not give them incentives for trapping their birds (Figure 4).

When asked whether parrot populations in their forests were increasing or decreasing over the year, $42 \%$ did not have an answer, while $31 \%$ said that they were increasing and $27 \%$ indicated that they were decreasing
(Figure 5). The number of Grey Parrots captured in an area over time can help wildlife managers and policy makers in taking management and policy decisions for the benefit of resources and the people. Figure 5 shows that $84 \%$ of the population did not know how many parrots were harvested from their forest and only $13 \%$ had an idea. It is an indication that sensitization is needed for the parrots to continue to thrive in the forest under the protection of the rural communities. There is also need to revamp the channels for information flow from the government to the communities and vice versa as a sustainable parrot conservation tool in Cameroon.

\section{Exporters and local traders}

The parrot trade is made up of a big network of people in Cameroon ranging from trappers in the villages through local traders to exporters (usually referred to as 'middlemen') in urban areas to consumers both locally and internationally. Middlemen can either be people who buy from trappers to resell locally or to export. Agents who sell within the country do not usually buy many birds at a time because they want to reduce the risk of taking care of a large number of birds, which is generally very expensive in the event of them not having many customers. The local sellers are not many in Cameroon and they are not comparatively wealthy people like the exporters. The local sellers hardly get permits to operate their businesses. Some local vendors sell to exporters when they have birds in a large stock. All middlemen depend on trappers, and some of them have up to 20 trappers spread in different parts of the country where there exist different species of parrots. They supply parrots to them on arrangements usually made through mobile phone calls or during particular periods of the month at specific prices.

Exporters cannot operate without permits or licences if they have to export their birds legally. By virtue of their legality, they have certain basic standards to meet in 
preparing their birds for export as required by MINFOF and CITES. We had difficulties in meeting local parrot sellers, and so most of the information was obtained from exporters.

All the traders contacted were literate, and $50 \%$ of them were high school leavers in possession of a GCE Advanced level certificate (Figure 6) while 17\% of them were university graduates with a bachelor's degree. Nearly all of them were married $(83 \%)$, with children and extended family members to take care of and some of them have children in universities both in Cameroon and abroad. The few that were not married, promised to get married. Marriage in the Cameroonian tradition is acceptance of responsibility to take care of a larger family, which implies an improvement in the source of income in which case they see the parrot trade as a good source of revenue.

The most preferred age of parrots in the trade (according to middlemen) is the young ones $(33 \%)$ followed by the rest of the age ranges with $20 \%$. Their primary reasons for preferring young parrots are that they are easily domesticated, less aggressive and can easily talk faster than the old ones. According to them, some customers prefer old parrots since they are more resistant to climatic and habitat changes and therefore have a higher probability to survive than the young ones. The number of birds that die (losses) with the middlemen before export was also of interest to the investigators (Figure 7). $33.33 \%$ of the respondents indicated that $0-3$ parrots out of the supply of 20-30 birds usually die. Another $33.33 \%$ of the interviewees stated that 3-5 parrots out of a supply of 20-30 birds often die (Figure 7). This high mortality rate, in this case, is enhanced by capturing techniques, handling and transportation method as well as the domestication process. Unfortunately, the trappers and middlemen hardly have any formal training in trapping and handling of the birds.

When the middlemen get the birds, they either exported them or sold them locally. Customers in Cameroon came principally from Douala (20\%), and the South West Region (Limbe, Buea, and Kumba) with $20 \%$. However, $40 \%$ of them got customers from Douala, Yaoundé and the South West Region. The Parrot trade is price driven. The higher the price, the more lucrative the trade and the more people will want to be involved. The ban on parrot exports from Cameroon by CITES from 2007-2011 brought a lot of problems to exporters who had stocks of parrots in their warehouses. Over two thousand parrots were in captivity in Cameroon of which some had been in this condition for more than one year pending export conditions to be favourable for export. Some of these exporters approached MINFOF, but the authorities were reluctant to refund their trading fees because all the money was deposited in the state treasury and so it was not easy to withdraw it.

Government: The Government of Cameroon is in charge of the conservation and management of wild parrots in Cameroon. The government policy is implemented directly through MINFOF or in collaboration with related ministries like the Ministries of Finance, Tourism, Environment and Nature Protection, National Security, and Agriculture and Rural Development. MINFOF has a special department headed by a director, which is in charge of Wildlife Management, Conservation and exploitation known as the Department of Wildlife and Protected Areas (DFAP). MINFOF also works with national and international NGOs and CITES to implement policies and developmental projects in forestry and wildlife management.

Trade management and regulation is the sole responsibility of the government. MINFOF is the major institution concerned with the management and control of the parrot trade in Cameroon. The major instrument used for trade administration and control is the 
1994 Forestry and Wildlife Law. Some results of this study were obtained from the central government in Yaoundé, and Regional and Divisional delegations of MINFOF. These results reveal the following:

\section{i. $\quad$ Issue of permits}

The licensing process is carried out in DFAP in Yaoundé. The number of legal exporters at the time of this study ranged from 10-20 for the past ten years. Some exporters have been in this business for over sixteen years. Though the law states that trappers are supposed to obtain licences, this is not usually carried out regularly. Exporters could sometimes trap the birds and have agents who work for them. In this case, they photocopy their licences and give to them to use for trapping parrots, practice that the Forestry and Wildlife law does not permit.

\section{ii. Parrot traffic and poaching control}

There are restrictions at checkpoints in most parts of the country, which are carried out regularly by MINFOF staff and other security departments such as police and Gendarmerie services. For controls of parrots in warehouses for exports, they said that this was carried out every three months by MINFOF staff.

\section{iii. Litigation}

Results of this study indicated that the number of offenders ranged from 0-2 per month. Most of the parrots were transported in public or private vehicles through checkpoints on highways by licence owners but poachers can go through the bush to escape inspections. The offenders are punished using the provisions of the 1994 Forestry and Wildlife Law. Seized parrots from criminals (smugglers or poachers) are:

a. Sent to the Mvog-Betsi Zoo in Yaoundé or the Limbe Wildlife Centre.

b. Publicly auctioned to legal exporters.

c. Publicly sold to the general public.

d. Rehabilitated and released.

MINFOF works with nongovernmental organisations in the country to handle the defaulters in wildlife products in general.

$$
\begin{aligned}
& \text { Royalties paid to the rural } \\
& \text { communities }
\end{aligned}
$$

The government does not pay any royalties to the rural communities protecting and conserving parrots (in particular) in their forests. There is a global sum paid by the government to communities for the exploitation of forestry and wildlife resources of their forests. The money for licences or permits and other levies are paid directly to the Ministry of Finance, and such money is used for public expenditure.

v. CITES AND MINFOF partnership

The government of Cameroon is a member of CITES. Hence, MINFOF works according to CITES rules and regulations for the parrot trade. The CITES yearly export quota for all parrots species was 12000 from 1998 to 2006.

\section{Export trade management and regulation}

Major suppliers of Grey Parrots are in the rainforest areas of Cameroon. At regional levels, three regions (South 31\%; Centre and East, 23\% each) are the major sources of Grey Parrots in the country. MINFOF leads export trade administration and control is assisted by the state security service. Border posts of Cameroon play a significant role in controlling export and import of parrots. This study shows that the airports are major points in the parrot trade. There is no official parrot trade with neighbouring countries like Nigeria, Chad, Central African Republic, etc. There are three international airports in Cameroon: Douala, Yaoundé-Nsimalen, and Garoua. However, the Garoua Airport hardly deals with commercial export of parrots. Official sources have it that the few parrots exported from Garoua Airport are for personal use or are smuggled.

Parrots are rarely transported by ship since too much time will be spent on the way before arrival at their final destination. Parrots 
are hardly imported into the country, but transit airlines do carry parrots and pass through the Douala and Yaoundé-Nsimalen Airports. Even if these parrots spend a few hours or days at the airport, the Chief of Post for Wildlife at the Douala Airport told us that proper handling services are given to them as they do to those from Cameroon. From the statistics obtained from the airports, the species of parrots exported is hardly mentioned in their documents. Any species of parrot is just recorded as a parrot. However, a field survey of warehouses of exporters by this study show that about $90 \%$ of them were Grey Parrots.

Available statistics indicate that 29,318 parrots were exported from 1996 - 2006 at the Yaoundé-Nsimalen Airport as opposed to 36,648 during the same period exported through the Douala Airport. The total number of parrots exported during this period of ten years was 65,966 (Table 1), giving a yearly average of 6,597 parrots.

The trade has become more popular as the traders make more money out of it and at the same time, more unpopular for conservation biologists and conservation NGOs. Conservationists argue that the trade is a potential threat to the continuous survival of wild parrots, especially in their range states. On the one hand, it is important to recognise and support the ecological role of the wild parrots in their various ecosystems. On the other hand, CITES in recent years has recognised the potential threat to wild parrots by the trade and has placed a lot of importance on the production of management plans to justify export quota determination. As a result of these on-going conflicts of interests, parrot export quotas are being regulated and restricted in many exporting countries.

\section{Key challenges of the parrot trade in Cameroon}

From questionnaire analysis, it is apparent that exploitation of parrots (legal and illegal hunting) accounts for about $32 \%$ of the conservation problems in this sector. Administrative problems associated with the parrot trade in Cameroon include the following:

1. Non-respect of exportation quotas: Many instances were recorded where Cameroon did not respect the CITES parrot export quotas. CITES has reacted to this excess exports by sanctioning Cameroon.

2. Non-regulation of capture: Nonregulation of capture, for instance, one parrot trapper could operate in many localities with the same permit and could trap as many parrots as possible using as many trappers as he can. At the end of a trapping season, he only declares the number that he is permitted to export. The rest can be sold locally or smuggled out of the country.

3. Corruption: Instances of corruption cases were reported in the parrot trade sector and some government officials were implicated.

4. Low level of local community involvement: There was a low level empowerment of the local communities in parrot conservation and trade management.

5. Too many permit holders: Too many permits were issued per year for parrot exploitation, and there was insufficient monitoring of their trapping activities in the field. In most cases, this deficiency leads to over harvesting and overexploitation of parrots. In the Mbang Sub-Division (Kadey Division) about 84,000 parrots were captured from 1997 to 2007 (information given by a former parrot trapper).

6. Insufficient staff personnel: There was insufficient staff personnel to carry out the required level of law enforcement (especially to track down parrot smugglers at the frontiers with neighboring countries), inventories and administration

7. Ignorant of the law: Most traders and government agents were unaware of the 
relevant sections of the Forestry and Wildlife Law related to their functions.

8. Lawis not adapted to realities: The Forestry and Wildlife law and its instruments of application were not adapted to realities of sustainable exploitation of parrots in the country. There is, therefore, the urgent need for the law to include policies on parrot conservation and management.

9. Control posts lack relevant documents: Control posts did not have copies of signed authorizations with which to work on verification and monitoring of transit parrot exploiters

Parrot smuggling and trafficking networks: There are two categories of smugglers in Cameroon.

Nationals: They smuggle and sell locally in big towns or traffic to neighbouring countries, where they are re-exported from that country.

Foreigners in the trade: A majority of immigrants in the trade in South-western Cameroon come from Nigeria and Ghana; in northern Cameroon, they come from Chad; and in the Eastern part, they come from Central Africa. They have agents in Cameroon who are nationals and collaborate with them to get the birds. They usually bring gifts as incentives to the village chiefs to obtain permission into their forests. Nigerians smuggle the poached birds to Nigeria by land, or sea and bribe their way through checkpoints. Ghanaians arrive along the Atlantic Coast and go back by boat to Ghana. This study discovered some of the routes used for smuggling and trafficking of parrots from Cameroon (Figure 8):

- From Magba and Bankim area to Kano in Nigeria. Nigerians who buy the parrots are mostly Hausas. While in Nigeria the smugglers export the birds as Nigerian parrots to Saudi Arabia, usually through Kano
Airport.

- From Douala and Tiko through the creeks by boat to Nigeria or to Ghana.

- From Mamfe, Kumba, Ekondo Titi and Mundemba by creeks and sea to Nigeria (Calabar Airport from where they are exported to Saudi Arabia) or to Ghana.

- From Lobeke, Moloundou to the Central African Republic.

- From Campo Ma'an, Kribi, Kye Ossi to Equatorial Guinea and Gabon.

- From Kousseri to the Chad Republic.

These routes were also used to smuggle parrot body parts, especially to Nigeria, South Africa and Saudi Arabia. Smuggling of live parrots and parrot parts in the country is common along the Cameroon - Nigeria - Chad - the Central African Republic and Equatorial Guinea borders. When the parrots from Cameroon arrive in the transit country, a certificate of origin and other documents are established in the country as parrots from that country for re-export. This trade is a significant loss to Cameroon for their resource to have a false identity in the international wildlife trade.

Parrot rescue and management: In Cameroon recently, five consignments of Grey Parrots were confiscated from illegal exporters. All of the five shipments were confiscated at Douala Airport, and four of them were being shipped to various destinations (Abidjan, Bahrain, Mexico City and Kuwait). Another group was seized along the Douala-Tiko road destined to be shipped to Nigeria through the small seaport of Tiko. According to information from the Limbe Wildlife Centre (LWC), two consignments were received in 2007 making a total of 1220 Grey Parrots. Out of this number, 261 (21\%) of them died, and $824(68 \%)$ were released (Table 2). In 2009, one consignment of 503 birds was received and from that number, 134 
(27\%) died, $151(30 \%)$ were released and the remaining stock that year was 218 Grey Parrots. In 2010, another consignment of 832 birds was brought to the Limbe Wildlife Centre and added to the stock of the preceding year to make a total of 1050 birds. Out of this number of birds, 216 (21\%) died, 834 (79\%) were released, and 99 of them were still in captivity by the end of the year (Table 3 ). During these three years, a total of 3,490 parrots were confiscated, 932(27\%) of them died, and 1,965(56\%) were released. Mortality rate per group ranged from $21 \%$ in 2007 to $45 \%$ in 2010. The report from the LWC explained that most of the parrot mortality incurred with the last parrot consignment as a result of dangerous trapping and handling techniques: many parrots died before and after arrival at the Limbe Wildlife Centre from multiple factors, including stress, poor feeding methods and glued feathers from trapping activities. When the PARROTPRO team visited the Limbe Wildlife Centre a few days after the arrival of the parrots, many of them were observed to be sick, dirty and stressed. By 23 May 2011, about 240 Grey Parrots were still in captivity at the centre pending treatment and subsequent release (Table 2).

Other problems identified were lack of cages for rescued parrots, lack of funds for management of the parrots, and lack of trained personnel for administration of the parrot trade etc. MINFOF, some NGOs and associated government security personnel have been doing a great job to crackdown parrot traffickers in the country recently. The staff of the Limbe Wildlife Centre (LWC) and its partner NGOs worked hard to raise funds and prepared the birds for release. There would have been fewer problems if the sector was well organized and sustainably managed by the government of Cameroon and associated NGOs. It should be noted that the major goal of the LWC is tilted towards the rescue and management of apes rather than birds. The parrots were housed in cages designed for apes and not for birds. A lot of difficulties were faced in relocating apes to create space to house the birds when each consignment arrived.

Wildlife law enforcement: Several NGOs and government agents and village communities are expected to enforce the wildlife law and regulations in Cameroon. Enforcement in this direction involves educating the people on the importance of the law and ensuring that the law is applied practically on the field. When applicable, arrest and prosecutions are levied on individuals contravening the law. Since 2007, MINFOF, LAGA, and WWF in collaboration with the National Security Forces have been involved in tracking down parrot poachers and traffickers in the country (Table 3). From 2007 - 2010, over ten lawsuits on parrot trafficking have been examined, and others are still awaiting judgement (Table 3) Cameroon.

Parrot trafficking is a big international network in Cameroon, and a majority of the foreign dealers identified came from Ghana and Nigeria with Cameroonian accomplices. All birds confiscated had their origin from forests in various parts of Cameroon. Most confiscations of the birds were carried out when the birds were being transported from one part of the country to another or were being smuggled out of the country. Trafficking activities were more frequent from 2007 upwards, following the moratorium on parrot export by CITES. Confiscated parrots were sent to zoos for rehabilitation and subsequent release. 


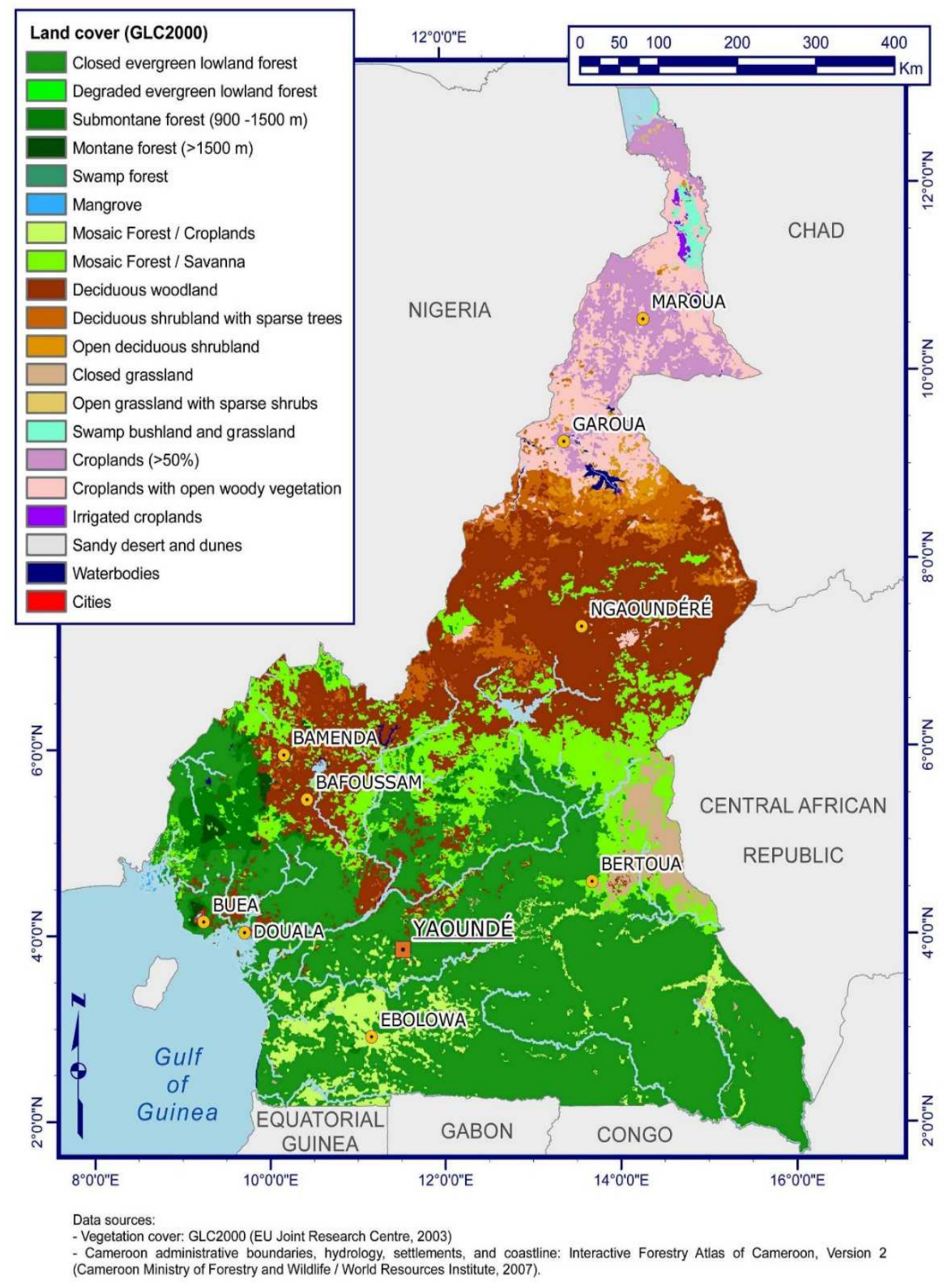

Figure 1: Vegetation diversity and border countries of Cameroon. 


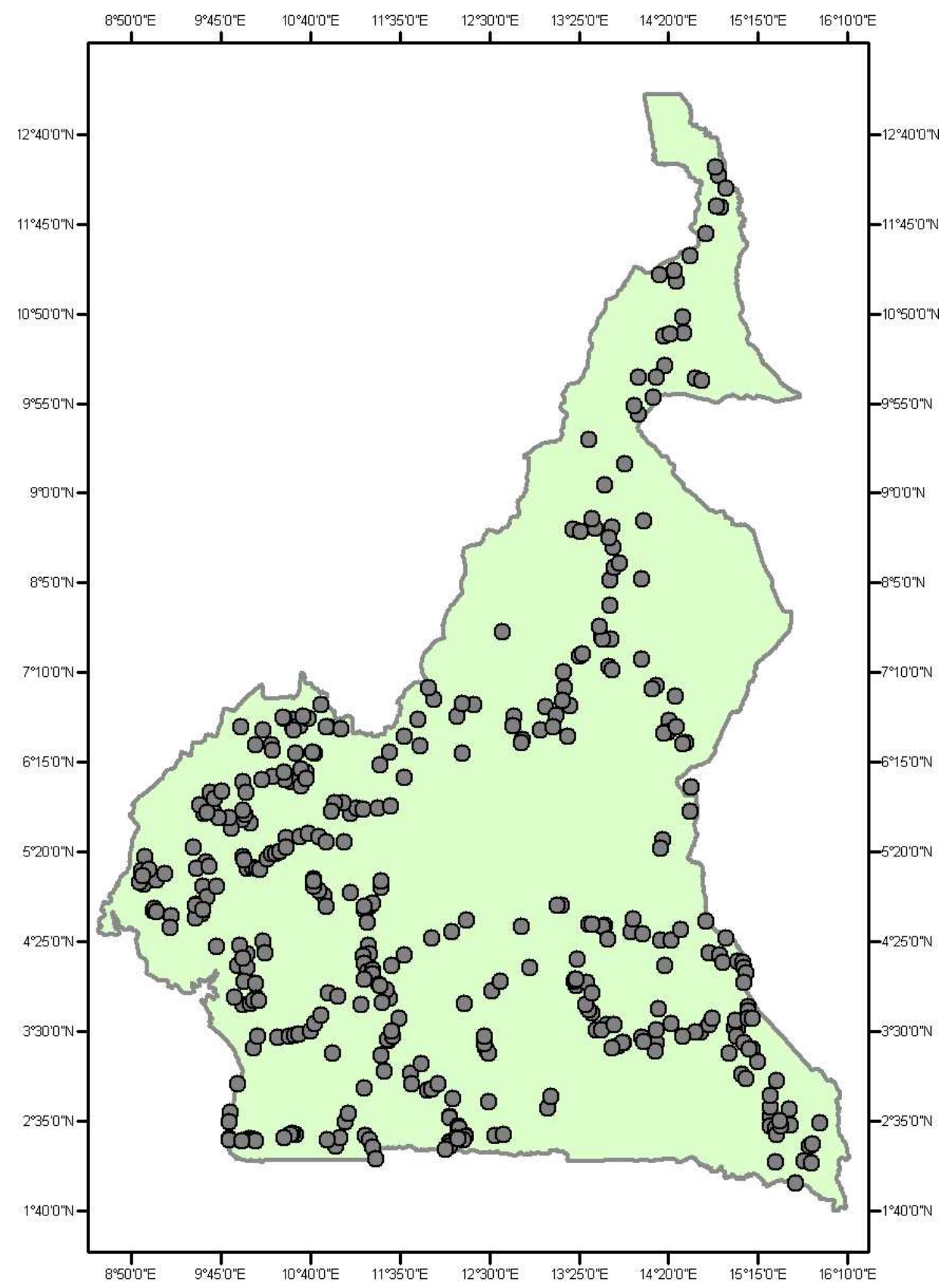

Figure 2: Sample points (represented by black dots) for questionnaire and focus groups data collection in the national territory of Cameroon and generated from a GIS coordinates collected during field survey. 


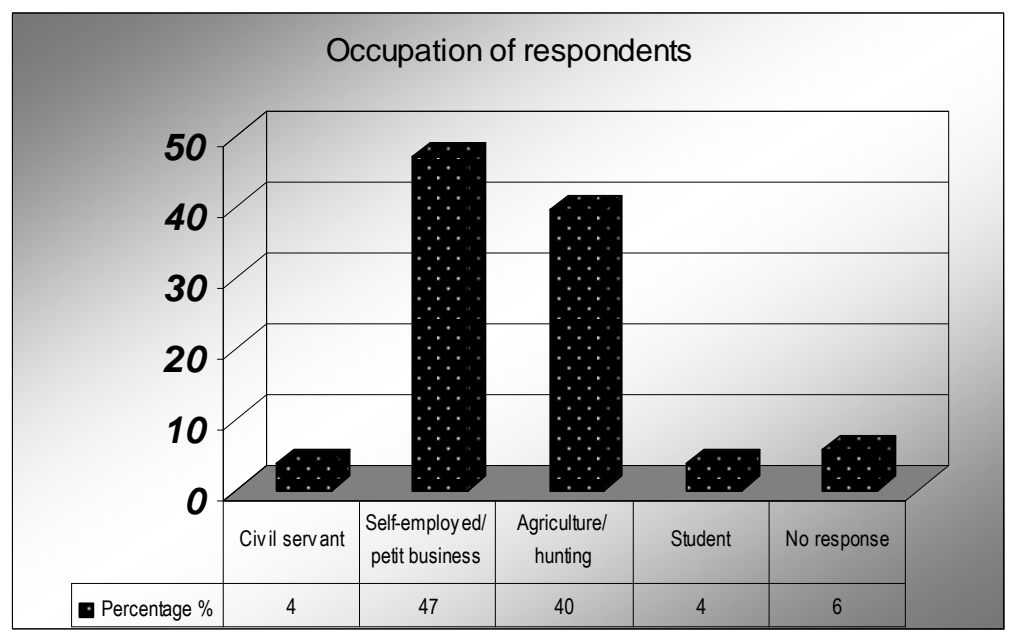

Figure 3: Percentage of various occupations of parrot trappers in both villages and urban areas.

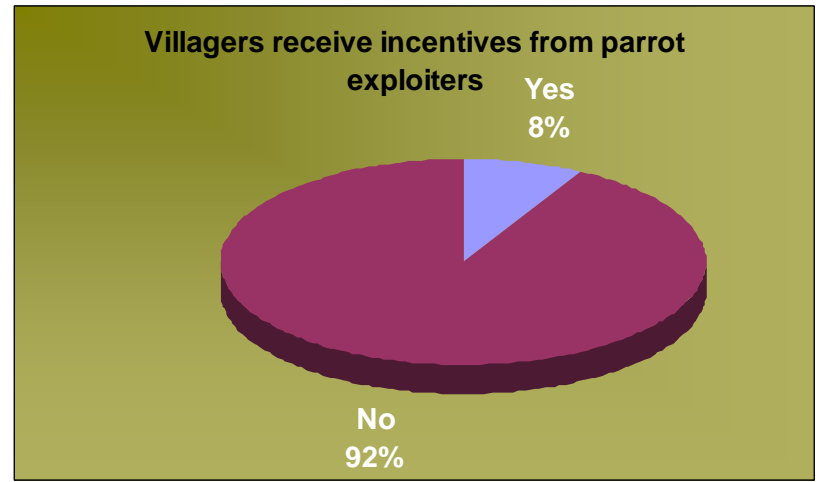

Figure 4: Distribution of responses on whether or not, parrot trappers give incentives as compensation to parrot conservation to villagers.

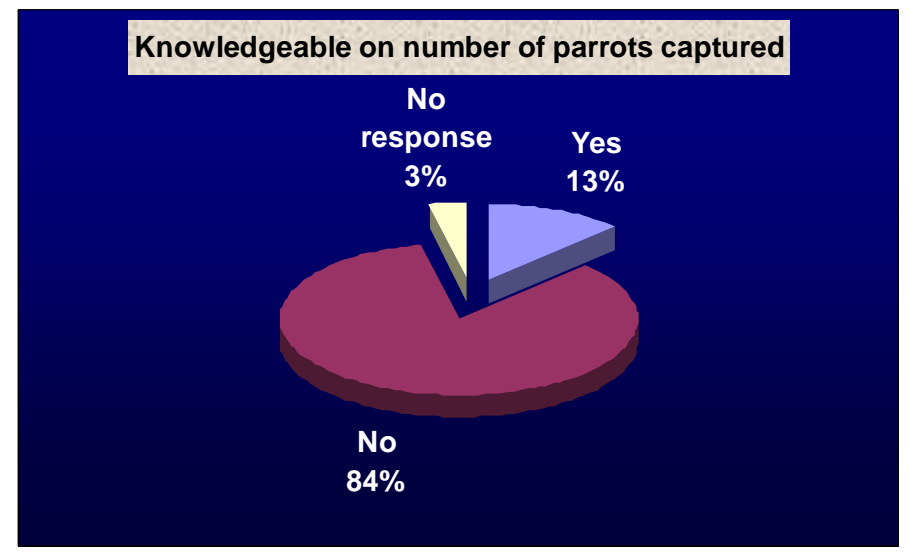

Figure 5: Knowledge of the quantity of parrots captured in forests in the country. 


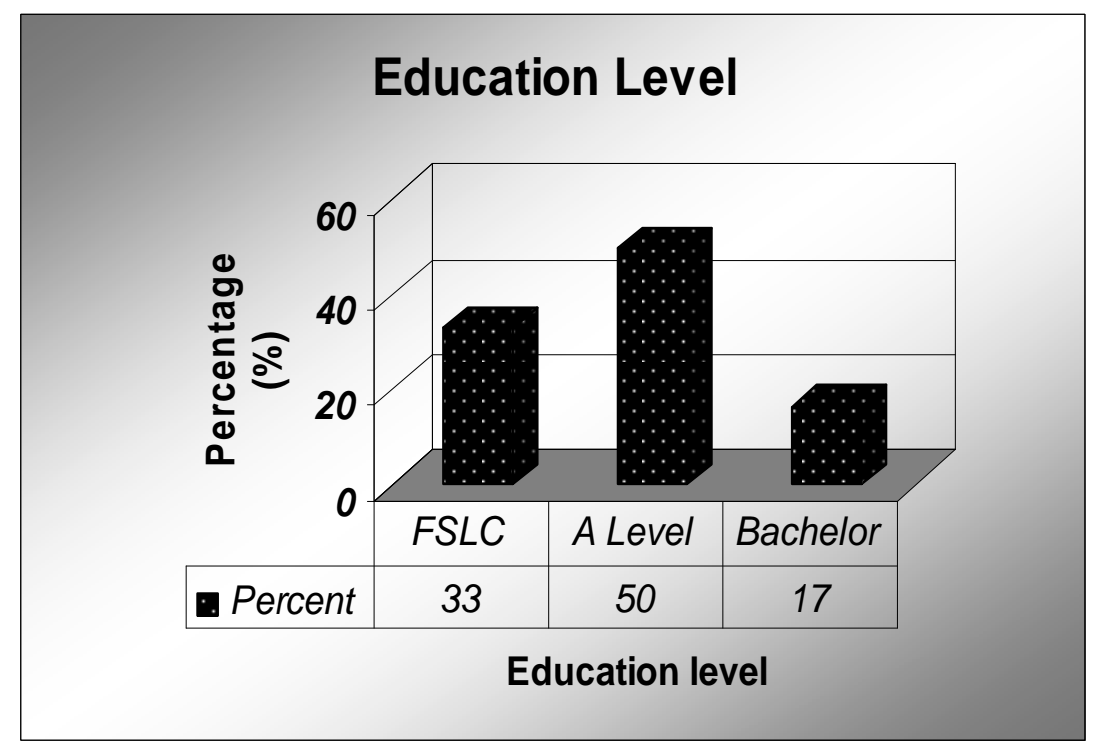

Figure 6: Evaluation of the educational level and qualification of parrot traders.

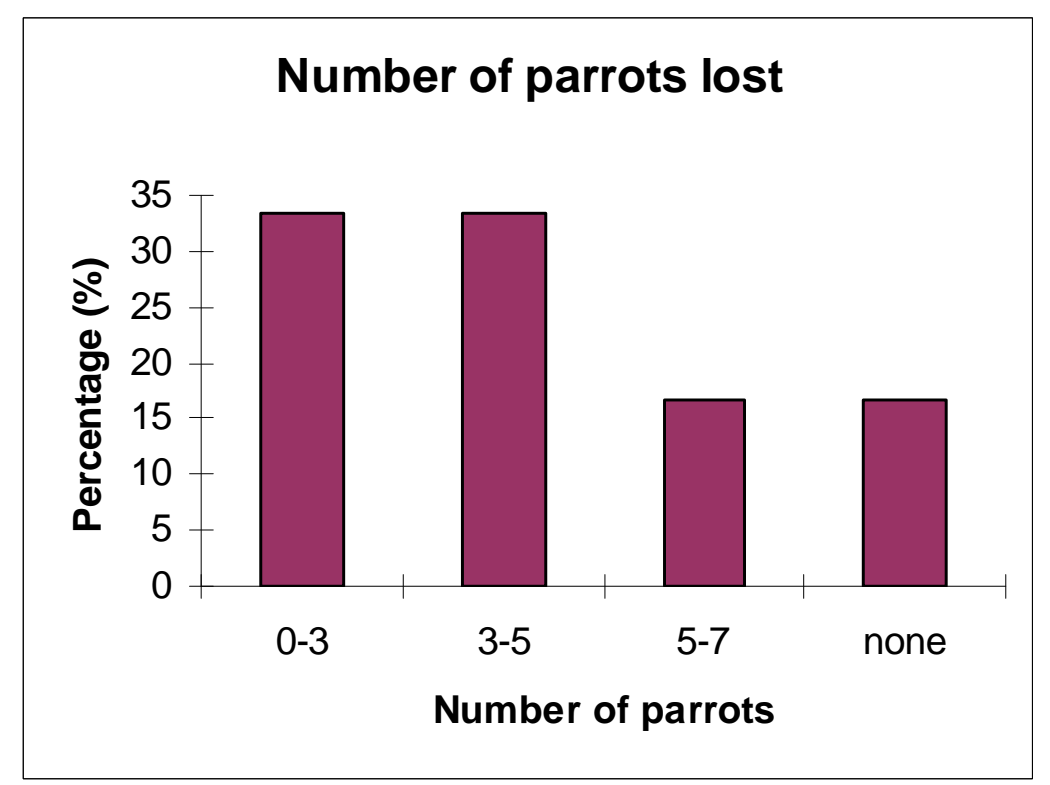

Figure 7: An estimate of the number of parrots lost per unit supply by trappers to traders in urban areas. 


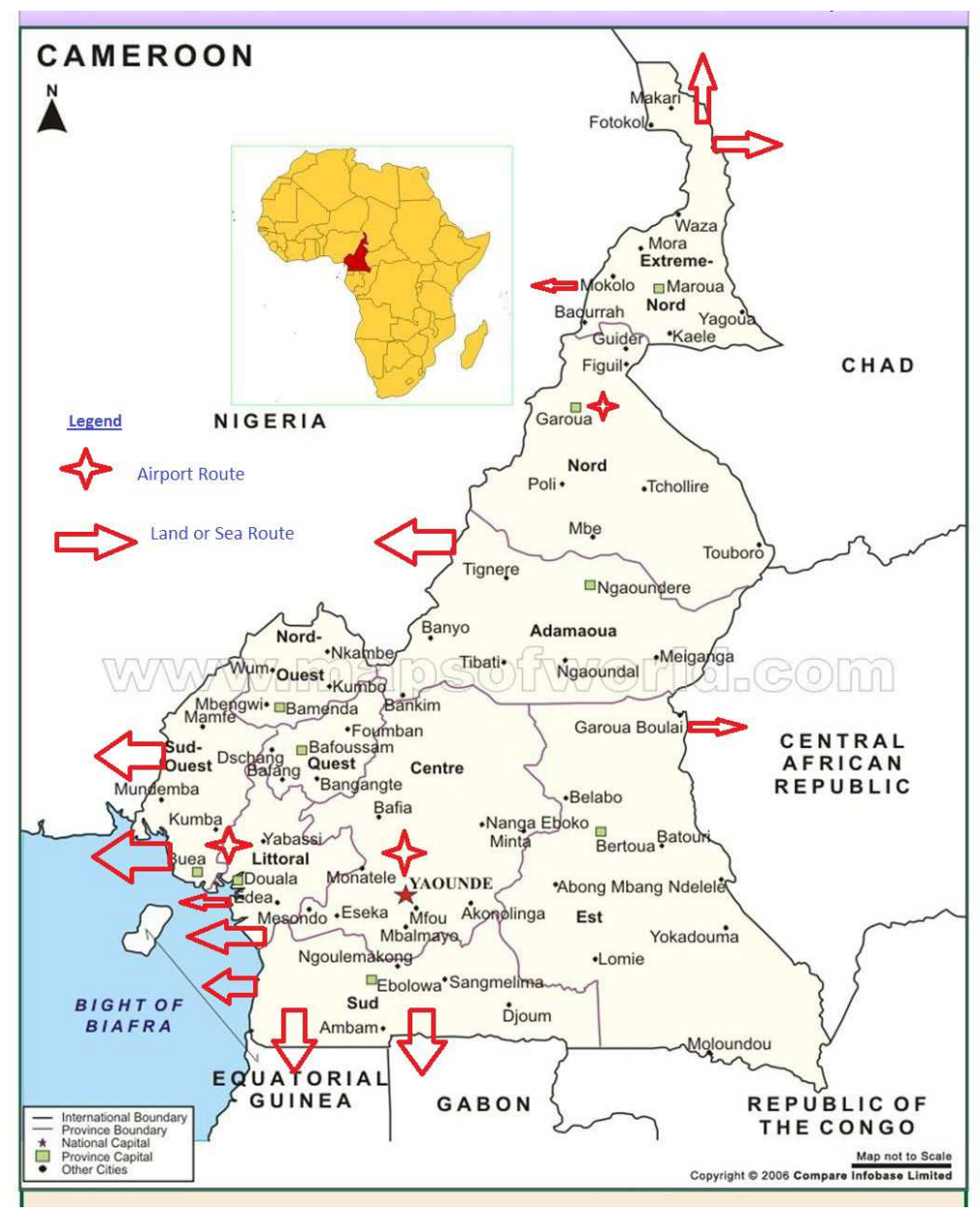

Figure 8: Major routes used for smuggling of parrots out of Cameroon. Map credit: Modified from www.mapsofworld.com

Table 1: Number of Parrots exported from Cameroon Airports from 1996 to 2006.

\begin{tabular}{cccc}
\hline Year & Nsimalen & Douala & Total \\
\hline 2006 & 0 & 2196 & 2196 \\
2005 & 2368 & 486 & 2854 \\
2004 & $?$ & 4930 & 4930 \\
2003 & $?$ & 4721 & 4721 \\
2002 & 1200 & 7780 & 8980 \\
2001 & 3750 & 5110 & 8860 \\
2000 & 5301 & 3340 & 8641 \\
1999 & 10180 & 1050 & 11230 \\
1998 & 5800 & $?$ & 5800 \\
1997 & 115 & 931 & 1046 \\
1996 & 604 & 6104 & 6708 \\
TOTAL & $\mathbf{2 9 3 1 8}$ & $\mathbf{3 6 6 4 8}$ & $\mathbf{6 5 9 6 6}$ \\
\hline
\end{tabular}

? : Data was not available for the years and Airports. 
Table 2: Rescued Grey Parrots and rehabilitation management by the Limbe Wildlife Centre from $2007-2010$.

\begin{tabular}{lcccccccc}
\hline Date & $\begin{array}{c}\text { GPs } \\
\text { arrived }\end{array}$ & $\begin{array}{c}\text { Old } \\
\text { stock }\end{array}$ & Total & Died & $\begin{array}{c}\% \\
\text { mortality }\end{array}$ & Released & $\begin{array}{c}\% \\
\text { Released }\end{array}$ & $\begin{array}{c}\text { Remaining } \\
\text { stock }\end{array}$ \\
\hline $12 / 2007$ & 1220 & 0 & 1220 & 261 & 21 & 824 & 68 & 0 \\
2009 & 503 & 0 & 503 & 134 & 27 & 151 & 30 & 218 \\
$02 / 2010$ & 832 & 218 & 1050 & 216 & 21 & 834 & 79 & 99 \\
$12 / 2010$ & 618 & 99 & 717 & 321 & 45 & 156 & 22 & 240 \\
Grand Total & 3173 & 317 & 3490 & 932 & 27 & 1965 & 56 & ---- \\
\hline
\end{tabular}

NB: \% mortality presents birds that were dead on arrival and those which subsequently died at the Limbe Wildlife Centre. Data Credit: Limbe Wildlife Centre, Cameroon.

Table 3: Arrest/prosecution of persons for parrot crimes by MINFOF, LAGA, national security and others from 2007 - 2010 in Cameroon.

\begin{tabular}{lll}
\hline No & Date & \multicolumn{1}{c}{ Arrest/Prosecution } \\
\hline $\mathbf{0 1}$ & July, 2010 & $\begin{array}{l}\text { 3 parrot dealers of Ghanaian nationality arrested in Cameroon were tried } \\
\text { in court and sentenced in Douala, Littoral Region. }\end{array}$ \\
\hline $\mathbf{0 2}$ & May, 2010 & $\begin{array}{l}\text { A parrot trapper belonging to a trafficking network was arrested in Kribi, } \\
\text { South Region, while trying to trade illegally in parrots. }\end{array}$ \\
\hline $\mathbf{0 3}$ & February, 2010 & $\begin{array}{l}\text { 3 international parrot traffickers were arrested in Douala, Littoral Region, } \\
\text { with more than 300 parrots seized. This arrest also exposed more } \\
\text { information on this illegal trade. }\end{array}$ \\
\hline $\mathbf{0 4}$ & January, 2010 & $\begin{array}{l}\text { Court case hearing started in Douala against 4 international parrot } \\
\text { traffickers following the seizure of 1000 parrots from them. }\end{array}$ \\
\hline $\mathbf{0 5}$ & December, 2010 & $\begin{array}{l}\text { 3 international wildlife traffickers arrested in Buea, South West Region } \\
\text { with about 700 parrots. Corruption attempts were observed from the } \\
\text { traffickers. }\end{array}$ \\
\hline $\mathbf{0 6}$ & December, 2009 & $\begin{array}{l}\text {-300 parrots were seized in Douala, Littoral Region. } \\
\text {-Court hearing started against 4 international parrot traffickers arrested } \\
\text { and detained in Douala. }\end{array}$ \\
\hline $\mathbf{0 7}$ & April, 2008 & $\begin{array}{l}\text { A manager of a logging company of Greek nationality arrested with 2 } \\
\text { live chimpanzees, 1 live De Brazza's monkey and 5 Grey Parrots in } \\
\text { Cameroon. }\end{array}$ \\
\hline $\mathbf{0 8}$ & November, 2007 & $\begin{array}{l}\text { 2 Ghanaians arrested in Douala Airport trying to export 500 parrots with } \\
\text { falsified documents. }\end{array}$ \\
\hline $\mathbf{0 9}$ & December, 2007 & An International Wildlife trafficker arrested in Douala with 720 parrots. \\
\hline & Data credit: www.laga-enforcement.org/
\end{tabular}

\section{DISCUSSION}

Cameroon is a biodiversity hotspot and has some of the most spectacular and finest wildlife species found in Africa (Bobo and Waltert, 2011; WRI, 2012; Sandjong et al., 2013; Ngoule et al., 2015; Tsakem et al.,
2015). Parrot species are an integral part of these assets which are part of Africa's biological heritage. At the same time, the country has a fast-growing human population, mostly rural dwellers, often living in poverty amid severe environmental degradation. The 
main causes of habitat degradation are poaching, overgrazing, bushfires, and fraudulent exploitation of forest resources such as parrots for livelihoods and exports. This problem is understandable because a majority of the rural dwellers depend on land for traditional agriculture, which is not sustainable with the current population growth rate and the continuous need for land for sustenance. Harvesting parrots and other wildlife resources for livelihoods and as a business venture is part of the daily lifestyle in this country (Ngenyi, 2003). This lifestyle has given rise to the international parrot trade, driven by the hobby of the quest for pets abroad (Birdlife International, 2016).

This hobby of keeping birds in captivity as pets varies from one culture to another in Cameroon in particular and around the world in general (Bush et al., 2014). For example, keeping parrots as pets is more prominent in cities like Douala and Yaoundé in Cameroon; and at the same time, it is not as pronounced in Africa as in Europe and the US. However, the hobby has given rise to the parrot trade in Cameroon, and it is big business involving the public and the private sectors. It begins with the trappers and villagers in the rural communities (who are custodians to parrot resources in their forests) and extends to the traders in towns and cities. The traders are of two categories: the smallscale operators who buy birds from trappers and sell locally as pets enthusiasts, and the richer traders who buy and export. MINFOF is the Government of Cameroon's representative in the trade thus MINFOF is the major body that implements the laws and regulations of the country in fulfilling the necessary obligations of the parrot trade. MINFOF also collaborates with CITES to determine exploitation quotas of parrots for a given time frame, determines individual quotas to be exploited by each trader and supervises export procedures until when the birds leave the country. Trappers and traders involved in the trade are dominantly selfemployed, subsistence farmers and hunters.
Civil servants and students of high school and the university also trap these birds as a parttime activity to augment their sources of income. The driving force behind the trade is poverty and unemployment. Trapping of the Grey Parrot, which is known to be a leading intelligent bird in the world (Pepperberg, 1999) is never an easy activity. The bird lives an arboreal lifestyle, roosting and nesting in very tall trees in the forest and only comes down to feed on lower trees and so, coupled with its intelligence, it is difficult to catch. Biodiversity Support Program (1993) pointed out that wildlife management can be a potential force in national development provided that economic growth improves the wellbeing of all members of the society. Cameroonians need a new kind of development that can rapidly improve the basic living conditions of the disadvantaged rural populations who are at the same time custodians of our wildlife resources. The international trade from Cameroon is also financially motivated as exporters get much higher prices per bird abroad than their local counterparts.

Out of the six species of parrots known to survive in Cameroonian forests, four were frequent in the trade: the Senegal Parrot (Poicephalus senegalus), the Red-headed Lovebird (Agapornis pullaria), Jardine's Parrot (Poicephalug gulialmi) and the Grey Parrot (Psittacus erithacus). The Grey Parrot is the most hunted bird in Cameroon (Tamungang et al., 2014). Thousands of Grey Parrots are captured each year for local consumption and export. The bird trade has been going on in Cameroon at varying scales for about thirty years. This study shows that Cameroon accounted for $48 \%$ of the Grey Parrots exported from all countries in Africa from 1990-1996. Before 1993, when CITES decided on restrictions on export quotas at 12000 birds, a yearly average of 14000 parrots was exported from Cameroon. Unfortunately, official figures do not account for parrots that are smuggled across Cameroon borders into neighbouring countries; those that are 
consumed and those that die in the process of trapping and transportation. Actual figures of harvested parrots could be higher than the official ones.

The trade in Grey Parrots from Cameroon started in 1993 to South Africa with 2095 birds (Mulliken, 1995). This study revealed that a yearly average of 14,000 Grey Parrots were exported from Cameroon before the restriction on export quotas by CITES in 1993. From 1993 - 2006, the CITES export quota for Grey Parrots from Cameroon was 12000 birds per year (Fotso, 1998). This quota was reduced to 3000 birds per year by CITES from 2012 (Tamungang et al., 2012). From 1981-2005, Cameroon exported 367166 with a yearly average of 15299. From 1990-1996, Cameroon exported $48 \%$ of the Grey Parrots in the 25 countries in Africa, thereby positioning itself as the leading exporter of wild Grey Parrots in the world.

Capturing methods vary from one part of the country to another but favourite techniques are the gum and stick, and nets. Some of the techniques have a probability of high mortality rates and kill indiscriminately. They include the use of chemical substances, guns and cartridges. Parrots are captured both in the day and night and all year round, but the Cameroon Forestry and Wildlife Law forbids night hunting. All sexes and ages are captured and no breeding season is observed. It is estimated that about $33 \%$ of $20-30$ parrots die before export by the traders. Most parrot deaths are as a result of poor handling and transportation difficulties because trappers hardly obtain permits. This shortcoming requires good trapping and handling techniques to be taught to those involved in the trade by MINFOF. Exporters are compelled to get permits and other documents from the government if they have to export their birds legally. They complained that the cost of preparing parrots for shipping was relatively higher in Cameroon than other African countries, thereby placing them at a disadvantage of the international parrot trade.
Parrots are used in many traditions in Cameroon such as traditional medicine, decorations, symbols of affluence, pets, companions, totems, security and messengers. Body parts are mostly used in traditional medicines and decorations. Prices of parrots vary in different regions of the country and are principally controlled by the place of purchase of the bird, buyer's personality, seller's personality and time or season of sell. Apart from the Grey Parrot that is sold in most parts of the country, the rest of the species in the trade are dominantly marketed in Douala and Yaoundé. The mean price for a pair of Lovebirds was 48.78 Euros. The average price of Jardine's Parrot was 27.44 Euros. The Grey Parrot accounted for over $90 \%$ of the parrots in the trade in Cameroon. The mean price of the Grey Parrot in Cameroon ranged from 350.49 Euros and the lowest prices existed in the rural areas while highest rates were obtained in the cities. Regions in Cameroon can be classified into three categories in descending order of price: Littoral and the North constituted the first group; Centre, Extreme North, Adamaoua, North West and South West, the second group; and the third group was constituted by the East, South and West Regions. Therefore, parrots were most valued in the Littoral and North Regions and least appreciated in the East and South. Paradoxically, the East and South supply over $56 \%$ of parrots in the trade. The rural people in these regions easily get parrots from their forests and sell them very cheaply to trappers or traders because they are not educated on the value of their parrots. Abroad, Cameroon parrots were sold for more than 100 times the price in the country. This price is not the net price as other expenses were not deducted. If they were deducted, the price or value of a Grey Parrot abroad would still be far higher than in Cameroon.

Conservationists argue that the trade is a potential threat to the continuous survival of wild parrots, especially in their range states (Wyler, 2008; Tamungang et al., 2014; Birdlife International, 2016). Depleting wild 
parrot populations is tantamount to reducing their useful ecosystem role in nature. CITES in recent years has acknowledged the potential threat to wild parrots by the trade and has placed a lot of importance on the production of management plans to justify export quotas (CITES, 2006). As a result of these on-going conflicts of interests, parrot export quotas are being regulated and restricted in many exporting countries (Conrad, 2012). There is a need for the exporters to come together and formulate a common strategy on how to maximize profits on parrots exported abroad. This measure may not involve only exporters in Cameroon but also exporters from other exporting African countries if the strategy is to be useful. The best approach for the government is to reduce anthropogenic pressures on parrot resources by educating the people and providing alternative sources of income (Biggs et al., 2015). Better still, the government should show them how to take care of these resources themselves. It is not too late for the Cameroon Government to seek lasting conservation measures that will help to improve the current forest habitat conditions of the parrots and other wildlife species.

\section{Conclusion}

The parrot trade is big business in Cameroonian society involving the public and the private sectors. The driving force behind the trade in this country is poverty and unemployment. Major suppliers of Grey Parrots are in the rainforest areas of Cameroon. At regional levels, three regions (South 31\%; Centre and East, 23\% each) are the major sources of Grey Parrots in the country. Trappers and traders involved in the trade are predominantly self-employed, subsistence farmers and hunters. MINFOF is the Government of Cameroon's representative and the regulatory body in the trade. MINFOF works with CITES to determine exploitation quotas of parrots for a given time frame. The Grey Parrot is the most exploited and exported wild bird species in Cameroon. Primary sources of Grey Parrots are the three rainforest regions of Cameroon. Trapping techniques vary from one part of the country to another. Some of the techniques are not sustainable for parrot conservation and are therefore not recommended for use. Parrots are captured both in the day and night and all year round, but the Cameroon Forestry and Wildlife Law forbids night hunting. All sexes and ages are captured and no breeding season is observed. It is estimated that 3-5 parrots die out of a supply of 20-30 before exportation by exporters. Most bird deaths are as a result of poor handling and transportation difficulties. The wildlife law in Cameroon is too generalized and does not take care of particular conservation needs of parrots. The International Bird trade will remain the subject of debate for some time to come, regardless of the forum for discussion. In this scenario, implementing the CITES treaty on wildlife trade remains a huge problem, as also does enforcing the stringent laws against wildlife smuggling that exist in many nations.

\section{COMPETING INTERESTS}

The authors declare that they have no competing interests.

\section{AUTHORS' CONTRIBUTIONS}

SAT, was the PARROTPRO Research Group Leader and data collector; RAC was the technical collaborator of PARROTPRO and data collector, MNT was the administrative and technical assistant; MAO was the socioeconomic assistant and data analyst; GPK was a $\mathrm{PhD}$ student in training and data collector.

\section{ACKNOWLEDGEMENTS}

Many people assisted us during the period of this study. We may not mention all the individuals who helped us here, but their collective, or individual contributions are highly appreciated. The University of Dschang provided office space and administrative support, and members of the PARROTPRO Research Group, who collected data. 


\section{REFERENCES}

AFA (American Federation of Aviculture) 2016. Legislative Issues - AFA Working with its members together. We Can Make A Difference, by Sandee L. Molenda. http://www.afabirds.org/ together_we_can_make_a_difference.s html

Biggs D, Cooney R, Roe D, Dublin H, Allan J, Challender C, Skinner D. 2015. Engaging local communities in tackling illegal wildlife trade: Can a 'Theory of Change' help? IIED. Discussion Paper. IIED, London. ISBN 978-1-78431-2367. ttp://pubs.iied.org/14656IIED

BirdLife International. 2016. Wild bird trade and CITES. http://www.birdlife.org/ worldwide/policy/wild-bird-trade-andcites

BirdLife International. 2004. State of the World's Birds: Indicators for our Changing World. An assessment from BirdLife Partners, Pp. 75.

BirdLife International. 2006. BirdLife International's review of the status of the African Grey Parrot and proposal to CITES for its conservation. $22^{\text {nd }}$ meeting of the Animals Committee. http://www.birdlife.org/action/change/c ites/grey_parrot_cites_2006.pdf.

Biodiversity Support Program. 1993. African Biodiversity for the Future. Smithsonian Libraries Prints: Washington DC.

Bobo KS, Waltert M. 2011. The importance of agricultural areas for bird conservation in the Korup region, south-western Cameroon. Int. J. Biol. Chem. Sci., 5(2): 419-432. http://ajol.info/index.php/ijbcs.

Brooks-Moizer F, Roberton SI, Edmunds K, Bell D, 2008. Avian influenza H5N1 and the wild bird trade in Hanoi, Vietnam. Ecology and Society, 14(1): 28. URL: http://www. ecologyandsociety. rg/vol14/iss1/art28/

Bush E, Sandra R, Baker E, Macdonald D. W. 2014. Global Trade in Exotic Pets
2006-2012. Conservation Biology, 28(3): 663-676. DOI: 10.1111/ cobi. 12240

Clemmons JR. 2002. Status Survey of the African Grey Parrot (Psittacus erithacus timneh) and Development of a Management Program in Guinea and Guinea-Bissau. Unpublished report to CITES, Geneva, Switzerland.

CITES (Convention on International Trade in Endangered Species of Wild Fauna and Flora). 2006. Psittacus erithacus. Twenty-second meeting of the Animals Committee, Lima (Peru), AC22, Doc. 10.2, Annex 1. http://www.cites.org/eng/com/AC/22/E 22-10-2- A1.pdf.

CITES. 2016. Investigating the internet wildlife trade. https://cites.org/eng/news/world/19/7.p hp Conrad K, 2012. Trade bans: a perfect storm for poaching? Tropical Conservation Science, 5(3): 245-254. www.tropicalconservationscience.org

FAO (Food and Agricultural Organisation of the United Nations). 1998. FRA 2000 Terms and Definitions. Forest Resource Assessment Programme Working Paper number 1 , Rome, Italy.

FAO. 2000. Global Forest Resource Assessment, Main Report.

FAO. 2010. Global forest resources assessment 2010: Main report. Rome: FAO.

Fotso R. 1998. Survey status of the distribution and utilization of the Grey Parrot (Psittacus erithacus) in Cameroon. Report to CITES in Geneva, Suitzerland.

GFW (Global Forest Watch) Cameroon. 2000. An overview of logging in Cameroon, A Global Forest Watch Cameroon Report, World Resources Institute, Washington D.C.

Hans-Ulrich Caspary, 1999. Wildlife utilization in Côte d'Ivoire and West Africa - potentials and constraints for 
development cooperation. TÖB publication: Germany.

Herrera M, Bennett H. 2007. Quantifying the illegal parrot trade in Santa Cruz de la Sierra, Bolivia, with emphasis on threatened species. Bird Conservation International, 17: 295-300. doi: 10.1017/S0959270907000858.

Hill D, Fasham M, Tucker G, Shewry M, Shaw P, 2005. Handbook of Biodiversity Methods: Survey, Evaluation and Monitoring: Cambridge University Press: Cambridge.

Inskipp T, Broad S, Luxmoore R. 1988. Significant trade in Wildlife: A review of selected species in CITES Appendix II. Volume 3: Birds.

Madindou I, Mulwa R. 2008. Some conservation aspects of the African Grey Parrot (Psittacus erithacus) in Kakamega Forest, Kenya: assessment of trade and habitat destruction effects. http://www.africanbirdclub.org/club/do cuments/GreyParrot Report II.pdf.

McGowan P. 2001. Status, management and conservation of the African Grey Parrot, (Psittacus erithacus) in Nigeria. Unpublished report to the CITES secretariat, Geneva, Switzerland.

MINEP (Ministry of Environment and protection of Nature). 2009. Cameroon Fourth National Report to the Convention on Biological Diversity. http://www.cbd.int/doc/world/cm/cmnr-04-en.pdf.

MINFOF (Ministry of Forests and Wildlife, Cameroon). 2007. Bref Aperçu du Secteur Forestier Camerounais. MINFOF: Yaoundé, Cameroon.

MINFOF. 1995. Law $N^{\circ}$ 94/01 of 20 January, 1994, fixing Forestry, Wildlife and Fishery regimes in Cameroon," Yaoundé, Republic of Cameroon.

Myers N. 1989. Deforestation rates in Tropical Countries and their Climatic Implications. Friends of the Earth: London.
Mulliken TA. 1995. South Africa's trade in Africa grey parrots' Traffic East/Southern Africa. Traffic International (1992). Perceptions Conservation and Management of Wild Birds in Trade. Traffic Inter. Cambridge U.K.

Mulliken TA, Broad SR, Thomsen JB. 1992. The wildlife bird trade: an overview. Perceptions, conservation and management of wild birds in trade. TRAFFIC Int, 1-42. Www.traffic.org/speciesreports/traffic_species_birds4.pdf.

Ngenyi A. 2003. The African Grey Parrot (Psittacus erithacus): status and commercial exploitation in Cameroon. Report for WWF, Jengi SE project, 40pp. http://camerounforet.com/system/files/18_13_29.pdf.

Ngoule C. C, Ngene J-P, Pouka M-C, Ndjib RC, Dibong SD, Mpondo ME. 2015. Inventaire et caractérisation floristiques des plantes médicinales à huiles essentielles des marchés de Douala Est (Cameroun). Int. J. Biol. Chem. Sci., 9(2): 874-889. DOI: http://dx.doi.org/10.4314/ijbcs.v9i2.26

Pepperberg IM. 1999. The Alex Studies. Harvard University Press: Cambridge.

Sandjong SRC, Ntoupka M, Adamou I, Toua $\mathrm{V}, 2013$. Etude écologique du Parc National de Mozogo-Gokoro (Cameroun): prospections préliminaires de la flore ligneuse et du sol pour sa conservation et son aménagement. Int. J. Biol. Chem. Sci., 7(6): 2434-2449. DOI: http://dx.doi.org/10.4314/ijbcs.v7i6.21

Tamungang SA, Cheke RA, Mofor GZ, Tamungang RN, Oben FT. 2014. Conservation concern for the deteriorating geographical range of the grey parrot in Cameroon. International Journal of Ecology, Article ID 753294, $15 \mathrm{p}$.

Tamungang SA, Cheke RA. 2012. Population status and management plan of the 
African Grey Parrot. SC62 Inf. 14. Review of significant trade report, prepared by the Ministry of Forestry and Wildlife, Cameroon to the $62^{\text {nd }}$ Meeting of the standing Committee of CITES, Geneva, Switzerland; 23-27.

Toufexis. 1993. All God's creatures priced to sell. Time Magazine, July 19, 1993(29) 36-4

Tsakem SC, Tchamba M, Weladji RB. 2015. Les gorilles du Parc National de Lobéké (Cameroun): interactions avec les populations locales et implications pour la conservation. Int. J. Biol. Chem. Sci., 9(1): 270-280. DOI: http://dx.doi.org/10.4314/ijbcs.v9i1.24

UNEP-WCMC (United Nations Environmental Program -World Conservation Monitoring Centre), 2009. Species Database: CITES-Listed Species.
http://www.unepwcmc.org/isdb/CITES/

Taxonomy/tax-species result.cfm/ isdb/CITES /Taxonomy/tax-speciesresult.cfm?Genus-Psittacus\&Specieserithacus\&source-animals. Forest cover data. Online at: http://www.wcmc.org.uk/forest/data

WRI (World Resources Institute). 2012. Interactive Forest Atlas of Cameroon. Version 3.0. Overview Report, World Resources Institute, Washington, DC, USA. www.wri.org

WWF (World Wildlife Fund). 1994. International Wildlife Trade: a CITES Sourcebook/Ginnete Hemley, Editor, ISBN 1-55963-348-2 Island Press: Washington D. C.

Wyler LS. 2008. International Illegal Trade in Wildlife: Threats and U.S. Policy. CRS Report to Congress, Order Code RL34395, 52pp. 